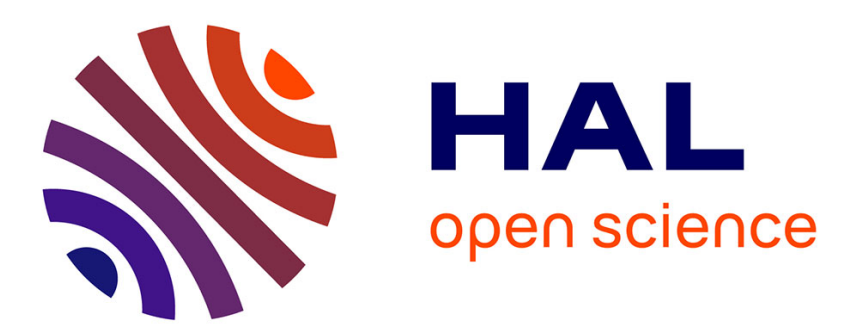

\title{
The flight of Icarus? Incheon's transformation from port gateway to global city
}

César Ducruet, Luis Carvalho, Stanislas Roussin

\section{To cite this version:}

César Ducruet, Luis Carvalho, Stanislas Roussin. The flight of Icarus? Incheon's transformation from port gateway to global city. Hall Peter V. and Hesse Markus. Cities, Regions, and Flows, Routledge, pp.149-169, 2012, Routledge Studies in Human Geography. halshs-00717425

\section{HAL Id: halshs-00717425 \\ https://shs.hal.science/halshs-00717425}

Submitted on 4 Dec 2012

HAL is a multi-disciplinary open access archive for the deposit and dissemination of scientific research documents, whether they are published or not. The documents may come from teaching and research institutions in France or abroad, or from public or private research centers.
L'archive ouverte pluridisciplinaire HAL, est destinée au dépôt et à la diffusion de documents scientifiques de niveau recherche, publiés ou non, émanant des établissements d'enseignement et de recherche français ou étrangers, des laboratoires publics ou privés. 


\title{
THE FLIGHT OF ICARUS? INCHEON'S TRANSFORMATION
}

\section{FROM PORT GATEWAY TO GLOBAL CITY}

\author{
César Ducruet $^{1}$ \\ Luis Carvalho ${ }^{2}$ \\ Stanislas Roussin ${ }^{3}$
}

\begin{abstract}
This chapter examines the relationship between freight and urban development in the case of the South Korean city of Incheon. Functionally linked to the capital Seoul as main gateway of the Gyeongin corridor, home to a major seaport (second after Busan) and new international airport, the local and national government have been especially aggressive in promoting all modes of freight transportation and logistics activity, as well as free economic zones, notably based on the "Pentaport" concept. The case of Incheon thus provides a site for exploring how (and with what consequences) cities in export-oriented Asian nations have gone about planning for heightened and elaborated flows of goods. Furthermore, it explores how logistic activities co-exist with the ambitions of Incheon - and South Korea as a whole - of becoming a Northeast Asia's knowledge and business hub. In light of the multiplication of other projects nationally and in Asia, and of the competition from Chinese manufacturers and transportation providers, this case provides some insights into what trends may emerge in the future.
\end{abstract}

\footnotetext{
${ }^{1}$ Corresponding author: French National Centre for Scientific Research (CNRS), UMR 8504 Géographie-cités, Equipe P.A.R.I.S., 13 rue du Four, F-75006 Paris, France. Tel. +33 (0)140-464-007, Mobile +33(0)626-602-163, Fax +33(0)140-464009. Email : ducruet@parisgeo.cnrs.fr

2 EURICUR \& Erasmus University, Rotterdam, The Netherlands

${ }^{3}$ Asem Institute, Seoul, Republic of Korea
} 


\section{INTRODUCTION}

Devastated by a fratricide war (1950-1953) followed by a decade of unstable economic policies, South Korea was in the early 1960s a land of deep poverty. Very rare were the experts able to predict that this rural country, deprived from natural resources, challenged by an unemployment rate above 20 per cent, continuously under the threat of a new War with its neighbour, and ruled by a military government, would have a bright future. South Korea is nowadays not only a stable democracy but also an economically dynamic and innovative Asian nation. It is the world's $13^{\text {th }}$ largest economy, excelling for example in shipbuilding, automotive, rolling-stock, steel, electronics and petrochemical industries. Underlying these developments was an export-oriented economic industrial policy based on strong alliances between the government, banks and a few entrepreneurs who built in less than 30 years some of the world's largest conglomerates. This success story has been dubbed the Han River miracle, backed by strong American, Japanese support and coordination of the South Korean people. More recently, South Korea could quickly overcome the severe financial crisis of 1997 without falling into a long term depression and even reach a GNP per capita of $\$ 20,000$ (USD) in the mid 2000s.

South Korea is still, and more than ever, an export-oriented country. As for 2011, the Korea Institute for Industrial Economics and Trade forecast that exports would reach $\$ 562$ billion (and imports $\$ 530$ billion), raising the annual trade volume over $\$ 1$ trillion for the first time in the country's history; its GDP in 2010 was also over \$1 trillion. However due to the division of the Korean peninsula between North and South in 1953, South Korea effectively remains an island with a high dependence on maritime transport: 99 per cent of its foreign trade is shipped by sea (Cullinane and Song, 1998), thereby giving strategic importance to Korean port cities such as Busan, Gwangyang, and Incheon. 
With a current population of over 2.7 million inhabitants in its Metropolitan Area, Incheon is the country's third largest city after Seoul and Busan. However, Incheon remains largely unexplored in the urban research and economic geography literature, namely when compared with Busan, the largest port (Frémont and Ducruet, 2005), and the capital Seoul (Hong, 1996). In fact, Incheon is part of the so-called "capital region" together with Seoul and the Gyeonggi province, ranking third after Tokyo and Mexico City in demographic size. The Capital Region is the country's main engine: with 22 million inhabitants it concentrates about 45 per cent of South Korea's population, 84 per cent of public services, 65 per cent of universities, 91 per cent of corporate headquarters, and 46 per cent of the country's GDP (Shin, 2005). Although territorial de-concentration policies of the early 1980s initially proved rather successful (Smith, 1981), their impact since then remains limited and congestion effects in the capital region have become critical (Choi and Ryu, 2000). Simultaneously, Incheon hosts since the late 1990s the world's second largest sea-reclamation project after Zuiderzee in the Netherlands (Wallace, 2004), and the largest private urban development project in the world (Lee and Oh, 2008), with the creation of Incheon International Airport (Winged City) and the launch of the Incheon Free Economic Zone (IFEZ) strategy in 2001.

This chapter investigates the local embedding of such recent projects and initiatives in their relation with freight flows and transport systems within Incheon and the capital region. The developments taking place in Incheon can (and should) be interpreted bearing Seoul's dynamics in mind; they are in many ways an extension of those. Seoul faces enormous problems of congestion, lack of space and a real estate crisis which are related with the location choice of Incheon for many of the ongoing developments, namely in close vicinity and possessing some advantages such as waterside location, existing infrastructure, and 
industrial base. However, the proximity to Seoul was seen by Fujita and Mori (1996) as a constraint to port-related urban growth. While Incheon's current development strategy to become a "world class global city" (IT Times, 2009) implicitly claims functional independence from Seoul, Incheon itself seems to have always been highly related with the capital city, their proximity being a catalyst or a constraint depending on the period considered:

1) Emergence of gateway and corridor (1870s-1960s): Incheon emerges as a major industrial and load centre in Korea following the Ganghwa Treaty (1876) and the opening of its port (1883) to international trade under Japanese pressure prior to the invasion (1910) and after the Korean War (1953);

2) Southward shift and relative stagnation (1960s-1990s): the southward shift resulted from major projects such as early free trade zones being located at other locations, partly due to physical limitations of Incheon's site, tensions with North Korea, and the national planning policy giving priority to Southern and Eastern regions;

3) Diversification and hub formation (1990s-2000s): in the 1990s Incheon's proximity to Seoul becomes once again an opportunity for economic development, illustrated by heavy investments in transport infrastructure, large scale urban development projects and new innovative sectors (e.g. Pentaport and free economic zone strategies - see next sections).

Nowadays Incheon particularly suffers from severe congestion problems due to high urban density, industrial sprawl, dominance of trucking flows, and scattering of development projects torn between different and overlapping logics and interests. This is combined with 
increasing unemployment and lowering economic welfare in recent years compared with the average score of all metropolitan cities in South Korea (see Figure 1). Other cities such as Busan exhibit similar trends but Incheon remains special due to the pace of change, which seems to contradict the projected benefits of current developments (even though many potentially high-impact projects are not yet completed). The analogy with the legend of Icarus alluded to in the chapter title is thus motivated by the apparent gap between Incheon's ambition to fly high among world cities and the internal tensions of its socio-economic and transport systems. Urban development, transport planning and its governance are thus key issues faced by Incheon where the smooth integration of transport and urban redevelopment is hindered by external pressures such as inter-city competition on national and international scales, dependence on private and foreign investment, and reliance on its gateway role with Seoul.

\section{Figure 1: Economic welfare and unemployment in Incheon}

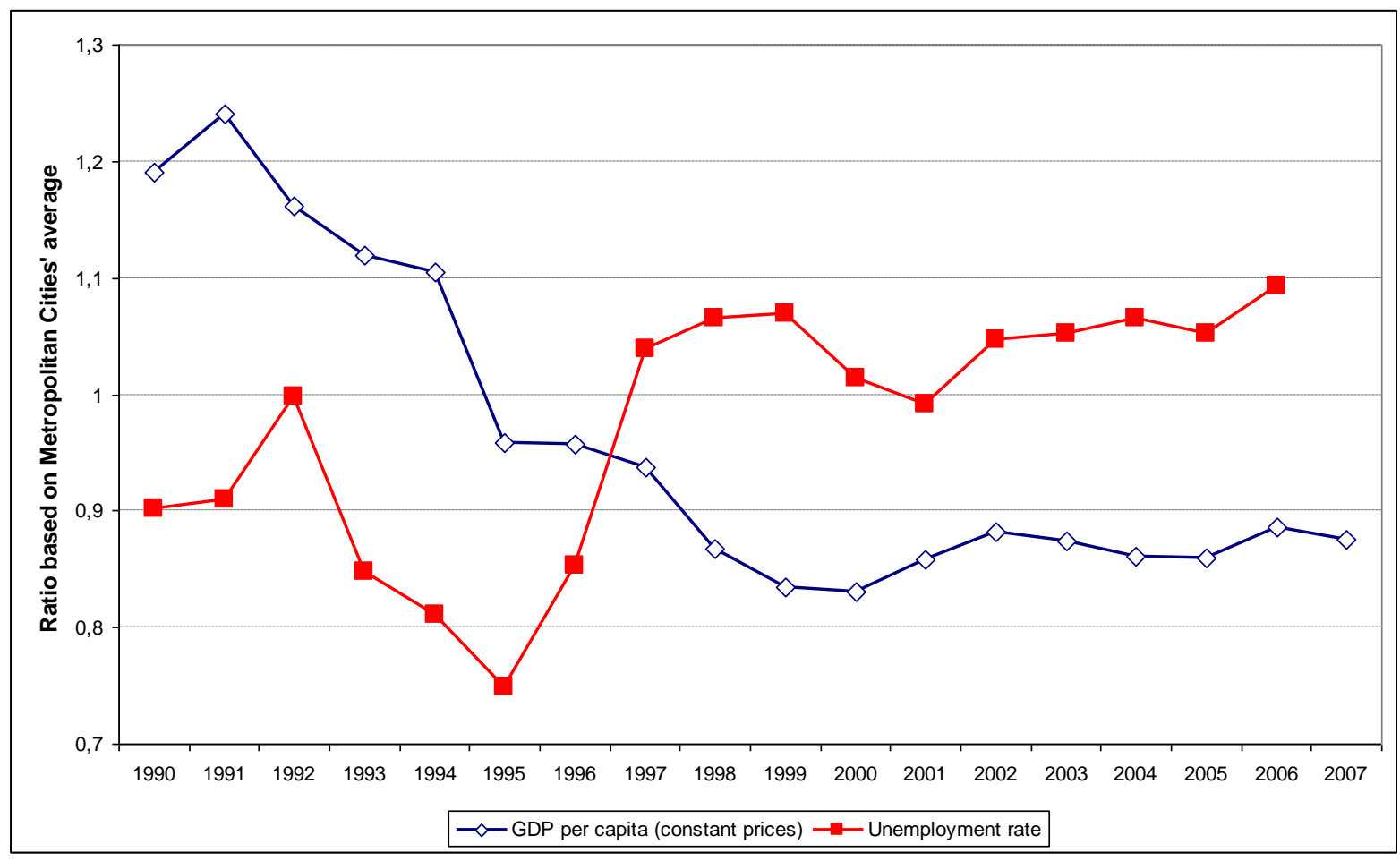

Source: own realisation based on OECD Territorial Database 
The remainder of this chapter is organized as follows. First we provide background on the emergence of Incheon and the Gyeongin (referring to Seoul-Incheon). corridor since the late nineteenth century, complemented by a look at the local impact of the "Han River miracle" on Incheon. Second, we focus on the policies and strategies pursued since the 1990s to turn Incheon into a new logistics hub and a prime location for innovative activities through the Free Economic Zone (FEZ) strategy. Third, by looking at the distribution of freight flows in recent years through Incheon airport and seaport, we provide evidence about Incheon's changing role as transport node at various geographic scales. In the conclusion, we propose to evaluate the gaps between the dynamics, the ambition and the action in the transformation of Incheon from port gateway to global city.

\section{SEOUL'S MARITIME GATEWAY AND THE GYEONGIN CORRIDOR}

\subsection{Industrial and port development in the early phase}

By the late $19^{\text {th }}$ century, the Ganghwa and Pyongja treaties initiated the transformation of Incheon from a small fishing village of 4,700 dwellers to a strategic gateway for foreign trade (Lee et al., 1998; Chung and Kato, 1998). This dynamic was reinforced by Japan's invasion of Korea (1910-1945) and the need for improving Seoul's maritime access through the construction of the Gyeongin Road (1899) and the Gyeonginson Railway (1900), which finally crossed the Han River in 1917. The development of load centre functions between Southern and Northern peninsula by the Japanese fostered a series of developments through land reclamation (30 per cent of Incheon's current territory has been sea-reclaimed) such as the bridge to Wolmi Island (1904) and the expansion of the port (1906-1912). Related economic and industrial developments were based on rice cleaning and brewery (1883-1910), weaving and milling (1911-1930), heavy industry and ammunitions (1931-1945), 
reconstruction, and manufacturing industries (1945-1960). Notably, Bupyeong district is the birthplace of Shinjin Automotive (1937) that would later become Daewoo Motor and then GM Korea. Such trends converged in the emergence of an industrial corridor between Seoul and Incheon (Gyeongin Industrial Region), notably with the completion of the first Gyeongin highway (1968). Incheon was Korea's leading port at the time of the Open Port Traffic Act (1961).

\section{Figure 2: Incheon and the Gyeongin corridor}

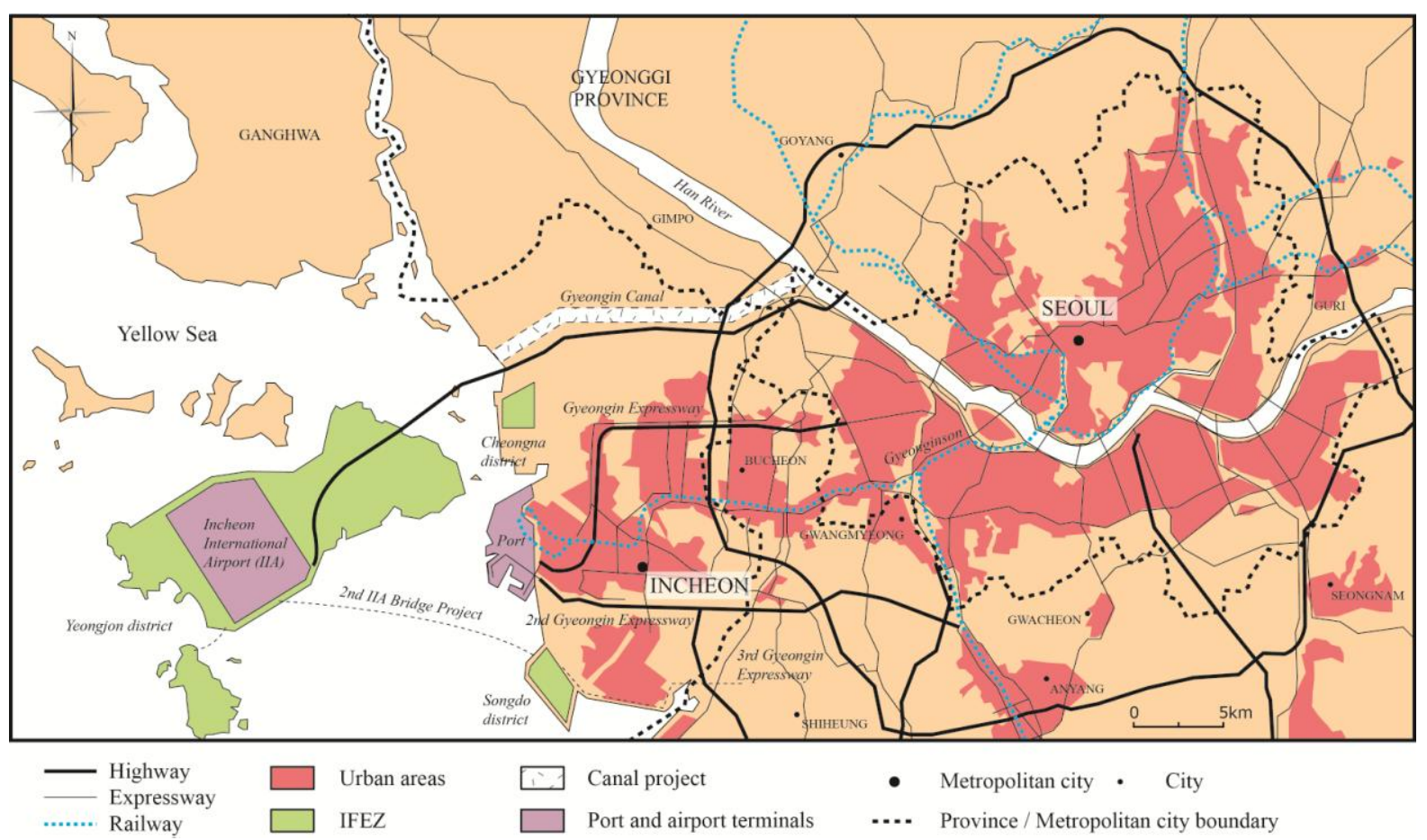

Source: adapted from Ducruet (2010)

A number of constraints soon appeared, however. Tensions with North Korea, proximity with Japan, and the strong regional ties of General Park Chung-Hee (Gelézeau, 2005) incited South Korean authorities to modernize south-eastern ports instead of Incheon, located too close to the DMZ (Demilitarized Zone). Naturally handicapped by high tidal ranges, Incheon quickly faced important limitations in terms of nautical accessibility. Busan notably benefitted from lesser war damage, deeper water depth, and population shifts, thereby facilitating industrial 
growth in the next decades (Frémont and Ducruet, 2005). Welcoming Korea's first container terminal in 1974 could not prevent traffic reorientation towards Busan, thus relegating Incheon to handling bulk cargoes (Rimmer, 2004a). Rapid urban growth, fuelled by rural exodus and industrial sprawl from Seoul, and the specialization in heavy industries and traditional activities resulted in the degradation of urban living environments and in the unplanned dispersal of activities around the port and along communication networks as in many other Korean port cities (Jun and Park, 1991).

\subsection{Rising spatial planning problems}

The aforementioned trends are long-lasting and are still visible nowadays on various levels, namely local, regional, and national. First, on the local level, while the whole city grew 24 per cent between 1990 and 2000, downtown areas lost 26 per cent of their population over the same period. This occurred as an effect of a suburban shift in context of intense real estate speculation (Incheon Metropolitan City, 2004) but also as a reaction to the ongoing dereliction of traditional industrial areas where living standards increasingly suffered from environmental degradation, deficiency in public services and cultural facilities (Kim, 2007), calling for revitalization (Kim, 2005). The Bupyeong industrial district is emblematic of recent changes in Incheon's urban geography. Notably, Lee (2004) examined the rather

passive role of the local government during the debt restructuring of Daewoo Motor in Bupyeong. His in-depth study of power relations confirmed the privilege given to "new" economic functions and "new districts" (see next section) as well as the paramount importance of the national government shaping urban affairs: "The local government actively engaged in the politics of forgetting by withdrawing from its alliance with the union to pursue its economic interest in upgrading Incheon's economic and industrial bases" (p. 2407). 
Second, on the regional level, significant increases in income, car ownership and shortage of available land combined with the multiplication of satellite cities and the scarcity of railway networks (Kim and Hwang, 2003). More than 60 per cent of passenger flows occur by road in the Capital region nowadays (Song et al., 2011). In parallel, the greenbelt policy around Seoul had the effect of raising rents by limiting land supply (Jun, 2011) while fostering the search for available land for new developments, notably in the Incheon area - which became linked with the local ambitions to develop new, post-industrial activities. However, local and regional authorities in Korea are still constrained by a long tradition of highly centralized government as most major projects are implemented top-down (Kim, 2007).

Third, on the national level, Incheon was de facto excluded from several industrial and planning policies. The first free-trade zones were located at southern locations (i.e. Masan, Gumi, and Iksan) for the aforementioned reasons of regional preference and proximity to Japan (Ducruet, 2010). The industrial de-concentration policy also favoured southern regions and second-tier cities (Lee, 1999; Park and Markusen, 1999). Since 2003 these policies also apply to the tertiary sector through the concept of the "multifunctional administrative city" and the creation of innovative and "enterprise cities" outside the capital region to foster balanced regional development (Kim, 2007).

Incheon's present situation is thus in the middle of such spatial and functional pressures. Traditional industries of the inner core become increasingly isolated from the rest of the city. Both national and local governments concentrate new investments at the urban fringe where cheaper land is available, thereby reinforcing local disparities and tensions between old and new areas. However, the "second wave" of free economic zone planning of the late 1990s 
clearly reaffirmed the importance of coastal and urban locations as economic engines and, in particular, reaffirmed the importance of Incheon's proximity to Seoul and the Capital Region. The question remains whether aiming to become the largest, urban-knowledge oriented free economic zone of the country as well as a major logistics hub in Asia can tackle, solve or at least minimize the long-term and complex inherited urban challenges of Incheon. We turn to these issues in the next sections.

\section{CURRENT PROJECTS AND URBAN TRANSFORMATIONS}

Current transformations taking place in Incheon directly reflect the goals stressed by the "2020 Incheon City Plan" designed by the Metropolitan Authority. Rimmer (2004a) notably underlined the strong reference of this plan to increasingly popular, western-focused concepts of "urban competitiveness" and "knowledge-based urban development", with all the caveats involved in the direct translation of those (per se problematic) notions to rather distinct contexts. This is in line with South Korea's post-1997 context favouring economic liberalization policies and openness to foreign capital (Carvalho et al., 2011). Place marketing dimensions of the Songdo project are notably studied by Kim (2010) with a particular emphasis on the concepts of green city and ubiquitous-city.

Those plans and visions have blunt physical consequences - therefore, investigating their coupling with inherited transport and flow dynamics is of paramount importance. Two (potentially) complementary directions/visions are analysed. First, turning Incheon into a centre of international business and distribution for Northeast Asia (see also Rimmer, 2004b); second, and related with the first, the development of environmentally friendly and top-level urban amenities and modern atmospheres envisaging the attraction of talents, investors and 
visitors. Two main instruments, one operational and one more conceptual, are used to realize such goals: the Incheon Free Economic Zone (IFEZ) and the Pentaport concept, respectively. Those are two sides of the same coin, i.e. the ambition to turn Incheon into a major business and logistics hub on regional and global scales. While the IFEZ proposes the development of three multi-functional new districts, the Pentaport notion focuses on the physical integration of transport functions within the city. These two dimensions are in line with current plans of Incheon city to introduce an intelligent, e-driven transportation system, home networking, tele-medicine, disaster prevention/monitoring, and a pollution controlling system by 2020 (Sang et al., 2008). We recall here the main directions and achievements made so far and discuss their ability to answer the city's wider socio-economic, flow-related challenges.

\subsection{The Incheon Free Economic Zone (IFEZ) concept}

The shift from port gateway to global city through the IFEZ strategy since 2003 is mostly based on the attraction of high-tech activities, which were previously developed at satellite towns around Seoul (e.g. Suwon and Paju). This is also a response to massive industrial shifts towards China and other Asian countries (e.g. Vietnam) in the manufacturing and electronics sectors (Carvalho, 2011). Three sea-reclaimed and non-contiguous districts constitute the IFEZ: Songdo, Yeongjong, and Cheongna (see Figure 3).

Sea reclamation around Incheon is not totally new, as seen with housing projects in the 1980s and the choice of Yeongjong island in the 1990s to develop the new international airport (see Figure 3). The City of Incheon then launched a so-called tri-port strategy (airport, seaport and teleport) based on international accessibility and the attraction of new industries like IT. Such visions gained momentum in the aftermath of the 1997 Asian financial crisis, as they became 
linked with the economic reforms towards the attraction of external investment and progressive liberalization of service industries (e.g. finance). In 1998 the Foreign Investment Promotion Act resulted in the creation of new Free Economic Zones (FEZ) while in 2002 the (entrepreneurial and business-oriented) Mayor Ahn Sang-Soo undertook the realization of the IFEZ. Nine years after the opening of the new international airport (2001), the new Incheon Grand Bridge linked Yeongjong and Songdo - the most emblematic face of IFEZ - in a 15 minutes car drive.

Figure 3: Land occupation at IFEZ new districts and main projects

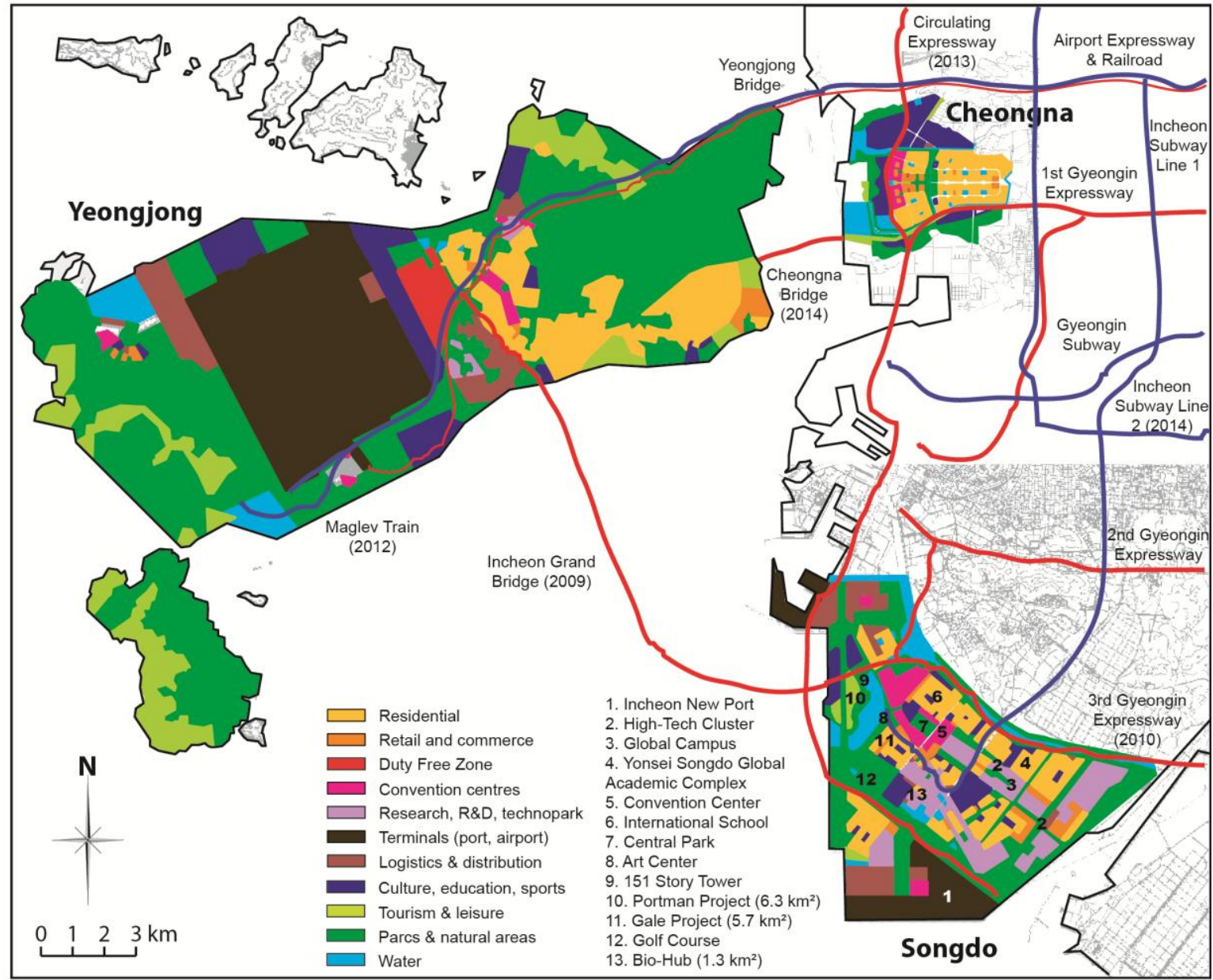

Source: own elaboration based on IFEZ (2009) and IDI (2010) 
The overall development of IFEZ has been a joint responsibility of the Ministry of the Knowledge Economy and the Incheon Metropolitan City, while involving many large private investors. The development of IFEZ as a test-bed of ongoing political, social and economic reforms in Korea also wishes to improve Korea's perception by external investors and expatriates (Kim and Lee, 2007). At the metropolitan and city level, by creating a new high stature business, logistics, leisure and knowledge hub, Incheon targets the activation of new and distinct growth engines within the capital region and Seoul (van Winden et al., 2011). It should however be noted that critics such as the Asian Development Bank have called for simplification of South Korea's scattered and confusing patchwork of 32 free zones, which are problematic in terms of environmental degradation and external readability (see Ducruet, 2010).

This complex and multifaceted project envisages a complete functional mix in dense and compact areas, integrating housing, working and leisure functions, as well as many amenities like parks, concert halls, hospitals, international schools, exhibition and convention centre, and golf courses. Spatially, IFEZ unfolds in a polynucleated area totalling $209 \mathrm{sq} \mathrm{km}$ based on three "new cities" having distinct vocations and ambitions (see also Table 1): Songdo is planned as a hub for international business, high-education, new high tech industries, and also container port facilities (see Figure 3); Yeongjong is the location of the international airport, focusing on air cargo and logistics, leisure resorts and (business) tourism; Cheongna is planned to focus on international finance, sports, leisure, and IT industry.

The development of IFEZ will take at least two decades to implement. Cheongna's development has barely begun, and in the face of the global economic downturn, there are concerns that this area will be removed from the original IFEZ plan altogether. In addition, 
Incheon currently faces high levels of municipal debt ( $\$ 7$ billion) due to the ambitious policy of former Mayor Ahn with huge spending on very large construction projects, and an unsuccessful Urban Future expo in 2009. Other difficulties are a consequence of the 2008 global financial crisis, notably resulting in delays for the construction of Songdo's highest tower due to unpaid building costs (Joongang Daily, 2011). So far, many apartment complexes remain empty, while potential residents wait for the completion of subway line 2 . The logistical and airport areas in Yeongjong are well developed, but all the other planned complexes are much more delayed. At present, few tourists visit the area and there seems to be little willingness to pay the bridge fee, thereby limiting the attraction of new residents. Songdo is the most advanced of the three sub-areas, as seen with the new residential areas, amenities, convention centres and high-tech industries, including many high-tech research complexes (of which some relocated from other locations). The development of a large new international university campus is on-going and the University of Incheon as well as Yonsei University (Seoul) relocated some departments in Songdo.

Table 1: The new cities of IFEZ

\begin{tabular}{|c|c|c|c|c|}
\hline $\begin{array}{l}\text { New IFEZ } \\
\text { cities }\end{array}$ & $\begin{array}{c}\text { Area } \\
\left(\mathrm{Km}^{2}\right)\end{array}$ & $\begin{array}{c}\text { Planned } \\
\text { population } \\
(2020) \\
\end{array}$ & Developers & $\begin{array}{l}\text { Major projects (ongoing and } \\
\text { planned, examples) }\end{array}$ \\
\hline Songdo & 53.4 & 253,000 & $\begin{array}{l}\text { Incheon Metropolitan City, } \\
\text { Songdo Technopark, NSIC, } \\
\text { Incheon Urban development } \\
\text { corporation, etc. }\end{array}$ & $\begin{array}{l}\text { Int'l business district, knowledge } \\
\text { and information industry complex, } \\
\text { bio-complex, high-tech cluster, } \\
\text { global university campus, leisure } \\
\text { park (e.g. Universal), Incheon new } \\
\text { port. }\end{array}$ \\
\hline Yeongjong & 138.3 & 169,000 & $\begin{array}{l}\text { Korea land corporation, airport } \\
\text { cooperation, Incheon Urban } \\
\text { development corporation, etc. }\end{array}$ & $\begin{array}{l}\text { Airport, tourism complex, leisure } \\
\text { complex, sky city, media-city, } \\
\text { logistics and distribution centre. }\end{array}$ \\
\hline Cheongna & 17.8 & 90,000 & $\begin{array}{l}\text { Korea land corporation, Incheon } \\
\text { Metropolitan City, Korea rural } \\
\text { community \& agriculture } \\
\text { corporation, etc. }\end{array}$ & $\begin{array}{l}\text { Global Finance/Business and } \\
\text { leisure, sports, R\&D centre, high- } \\
\text { tech industry complex (automotive, } \\
\text { "Robotland"), Floricultural } \\
\text { complex. }\end{array}$ \\
\hline
\end{tabular}

Source: IFEZ (2010) 
Many private investors (Korean and American) cherry picked this area due to its privileged connection to the airport and strong public support (e.g. land prices and flexible regulations), and the development remains buoyant. The dominance of housing functions harms the vibrancy, urban atmosphere, and multifunctional character of other similar Asian projects such as Pudong in Shanghai. Yet, Songdo and its "Central Park" are becoming popular for dining, while local schools gain increasing reputation: a key factor to attract residents and to rise real estate value.

\subsection{The 'Pentaport' concept}

The Pentaport concept is an extension of the aforementioned tri-port strategy proposed by the Ministry of Maritime Affairs and Fisheries (MOMAF) (Kim, 2000) and adopted by Incheon Metropolitan City to value the strategic situation of Incheon in Korea and Northeast Asia (Chang, 2003; Rimmer and Chang, 2004). Airport and seaport should combine with teleport (or technoport), business port, and leisure port, but the functional and spatial principles of such integration remain unclear in the discourses. Miller and Kim (2004) rightly state that "Pentaport/City-hub" would better express the urban grounding of the concept.

Although not clearly defined, the Pentaport idea has gradually been applied in several ways, besides the expansion of port facilities (North Incheon Port, Incheon Container Terminal). The Gyeongin Canal, completed in late 2011 but still only used as a promenade, was designed to reduce trucking with Seoul and to lower logistics costs with China, using 5,000 tonne freighters and ferryboats directly connecting Seoul city centre (Ship-Technology, 2011). Despite concerns from environmentalists about the real economic impact of the project 
(Hankyoreh, 2009), the canal is expected to accommodate containers (about 970,000 TEUs per year) and other products (steel, cars, sand) as well as passengers. Among the seven Korean international airports, Incheon is the largest. It was ranked 4th in the world ranking of cargo tonnage in 2009 (39th for passengers), and handles more than 97 per cent of South Korea's air freight, although only 0.4 per cent of South Korea's trade occurs by air transport overall (Roth, 2011). Incheon International Airport (IIA) regularly receives praise for its service quality and performance by various international organizations.

The Pentaport concept also applies to the efficient interconnection of IFEZ districts, such as between Songdo and Cheongna (second highway belt of Seoul), Songdo and Yeongjong (second bridge connected with the planned third Gyeongin highway), Songdo and south Gyeonggi province (highway bridge, third Gyeongin highway), and Cheongna and Western Incheon (Gyeongin highway extension). Although the subway system is currently becoming more integrated with the extension of lines $1,2,4$, and 7 , together with a new railway link (Seoul-Yeongjong) and new subway stations, there is a tendency to favour the Seoul-IFEZ axis, as reflected in the limited integration of Incheon in the bus transport system of Seoul and Gyeonggi. Internally, the $\$ 772$ million Wolmi Galaxy Rail (monorail) is currently suspended and about to be dismantled atr a cost of $\$ 23$ million due to corruption and overestimation of local budgets.

In addition, congestion issues remain only partially answered. The relocation of some activities from Incheon old core and Seoul to IFEZ districts generated new commuting flows (e.g. airport-Songdo-Seoul), in addition to already existing ones, notably related with the port (see Figure 3). It was argued by Jun (2003) that the inclusion of neighbouring localities such as Shiheung, Ansan, Gimpo and Pyongtaek in the IFEZ project would have enhanced local 
integration. Pyongtaek, located about $40 \mathrm{~km}$ south of Incheon, is a direct rival of Incheon as it is a growing container port and the heart of the Yellow Sea Free Economic Zone. There is certainly some hope to absorb more commuting flows with the completion of the Suin Line (Suwon-Incheon) and of Line 2. The Songdo area is attractive for foreign companies due to its (still) light traffic congestion compared to Seoul's Central Business District. Official plans of Incheon Metropolitan City to redevelop and regenerate other (older) areas in the city based on real estate profits have yet to be implemented. The extent to which internal dynamics are reflected in the position of Incheon in the regional transport system are discussed in the next section.

\section{THE CHANGING PATTERN OF PHYSICAL FLOWS}

\subsection{Incheon as Yellow Sea hub}

The proximity with Northern China as well as the lower cost of land transport between Seoul and Incheon compared with Seoul and Busan gradually created an opportunity for Incheon to develop transhipment activities despite its physical limitations (Choo, 1998; Lee and Rodrigue, 2006). Following the first Korea-China freight link (1989) excluding Incheon, several new services were launched during the 1990s mostly based on passenger traffic; it is only in the 2000s that containerized trade grew significantly at Yellow Sea ports, with a sustained bypass of Busan. Incheon increased its share in the Korean port system from 8 per cent in 1991 to 10 per cent in 2004, while Busan decreased from 67 per cent to 46 per cent. This was mostly due to domestic competition from secondary ports such as Pyongtaek for short-sea shipping, and a twin-hub strategy favouring Gwangyang for deep-sea shipping (Lee and Kim, 2009). During that period, Incheon strengthened its centrality in the Northeast Asian 
liner shipping networks, by becoming a hub for several North China ports and becoming third most central port in 2006 after Busan and Hong Kong (Ducruet et al., 2009a).

Another dimension of hub formation has been the development of air-sea cargo transfer at Incheon airport to and from nearby Chinese port cities (Park, 2003). Because air transport infrastructure in many regional Chinese cities is lacking, an increasing amount of cargo (e.g. textile) is shipped by some multinationals (e.g. NIKE) from China to Incheon port for being exported through the airport (Table 2). The evolution of this specific niche has been fast, although its remains secondary vis-à-vis total airport cargo throughput: from 33,000 tonnes in 2003 (1.8 per cent) to 60,000 tonnes in 2009 (2.6 per cent) (Roth, 2011). Such services have the advantage of reducing from three weeks to one week the delivery time between China and overseas importers. As presented in Table 2, most air-sea traffic is realized with Yellow Sea Chinese cities located in Shandong and Liaoning provinces, followed by Shanghai and Tianjin.

The proximity with North Korea became another opportunity during the early 2000s, in the context of warmer North-South political relations and growing inter-Korean trade backed by the Gaeseong Industrial Park near the DMZ and a maritime agreement. Incheon gradually concentrated North-South shipping flows as well as a growing proportion of total North Korean traffic, especially with Nampo, Pyongyang's gateway (Figure 4). Although more recent figures are unknown and might reveal a decline in inter-Korean traffic due to prolonged tensions on the peninsula and persistent crisis in North Korea, Incheon's share reached about 30 per cent of North Korea's totals in recent years (Ducruet et al., 2009b). The same figure for containers even reached 54 per cent in 2003 and 82 per cent in 2006, a stark contrast with the average of 5-10 per cent during the 1980s and 1990s. While such trends 
reveal ongoing North-South economic integration processes they also point at North Korea's growing economic difficulties.

Table 2: Air-sea cargo flows between Incheon and Chinese port cities (Unit: tons)

\begin{tabular}{cccccccc}
\hline Port of origin & $\mathbf{2 0 0 3}$ & $\mathbf{2 0 0 4}$ & $\mathbf{2 0 0 5}$ & $\mathbf{2 0 0 6}$ & $\mathbf{2 0 0 7}$ & $\mathbf{2 0 0 8}$ & $\mathbf{2 0 0 9}$ \\
\hline Qingdao & & & & $19,961.9$ & $17,131.8$ & $18,627.9$ & $15,484.0$ \\
Yantai & & & & $3,699.9$ & $7,562.5$ & $14,047.8$ & $14,815.2$ \\
Shanghai & & & & $8,930.2$ & $9,674.6$ & $12,005.7$ & $7,917.3$ \\
Weihai & & & & $8,104.7$ & $7,292.1$ & $8,577.5$ & $7,857.8$ \\
Shidao & & & & 197.2 & 112.3 & $2,312.6$ & $4,782.1$ \\
Tianjin & & & & 745.4 & 933.4 & $1,155.4$ & $2,990.2$ \\
Long Yan & & & & - & 585.2 & 332.0 & $2,441.1$ \\
Dalian & & & & $2,399.1$ & $2,151.9$ & $2,730.4$ & $2,121.8$ \\
Qinhuangdao & & & & - & 226.6 & - & 401.9 \\
Lianyungang & & & & - & - & - & 347.5 \\
Rizhao & & & & 371.3 & $1,096.6$ & $1,039.4$ & - \\
Shekou & & & & - & - & 185.0 & - \\
Yingkou & & & & 140.5 & - & - & - \\
\hline Total & 33,437 & 39,415 & 44048 & $45,245.4$ & $47,111.7$ & $61,477.9$ & $59,612.7$ \\
\hline Share (\%) in total & \multirow{2}{*}{1.81} & \multirow{2}{*}{1.85} & \multirow{2}{*}{2.05} & 1.95 & 1.86 & 2.52 & 2.58 \\
airport cargo traffic & & & & & & & \\
\hline
\end{tabular}

Figure 4: Inter-Korean maritime container flows, 1985-2005

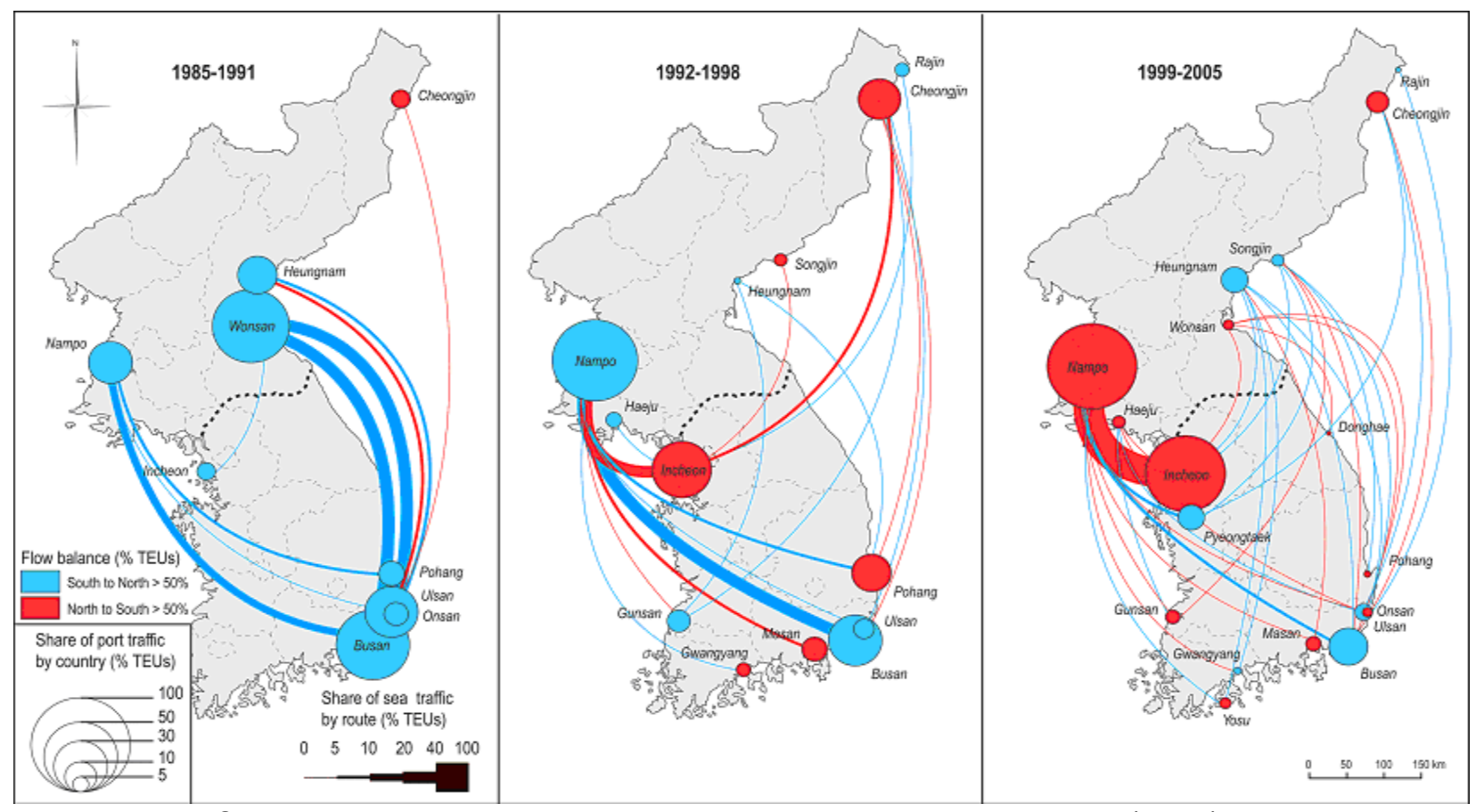

Source: own realization based on Lloyd's Maritime Intelligence Unit (LMIU) 


\subsection{Concentration and dispersion of hinterland flows}

Recent figures on the spatial distribution of port-related cargo flows confirm Incheon's lasting dependence upon the Capital Region, which concentrates about 90 per cent of Incheon's total traffic. Incheon itself accounts for about 60 per cent of tonnage due to the presence of very large industrial complexes and a large population (Figure 5). While hinterland patterns are comparable between imports and exports, we observe a spatial shrinkage of the import hinterland, which concerns heavier traffic due to Incheon's role as an import gateway. Between 2006 and 2009, Incheon and Seoul have increased their respective shares from 60.5 per cent to 64.6 per cent and from 14 per cent to 15.8 per cent. By contrast, distant regions such as Chungcheong (6.6 per cent to 4.6 per cent), Gangwon (2.3 per cent to 1.1 per cent), Gyeongsang (2.6 per cent to 1.7 per cent), and Jeolla (2.7 per cent to 0.6 per cent) have witnessed a regular decrease of both their import traffic volume and share in relation with Incheon port. Mainly because of cheaper land prices, many logistics and distribution centres moved from Incheon to Pyongtaek in recent years. As a result, export flows from outside the Capital Region have increased in proportion to import flows from 10 per cent to 26 per cent along the period. The geographic pattern of export hinterlands has remained rather stable during the same period, notwithstanding a regular increase of the traffic volume and share of Seoul (13.2 per cent to 20.1 per cent) but also Busan and Gyeongsang province, the two latter generating rather negligible volumes.

The higher spatial flexibility of containers is reflected in their wider geographic coverage and the lower share of Incheon city (20-30 per cent) and the capital region (60 per cent) in total hinterland traffic, while the share of the rest of country has increased from 13 per cent in 2006 
to 21 per cent in 2009. This underlines the specialization of Incheon in non-containerized freight flows as mentioned above. The capital region has slightly lost market share, from 65 per cent in 2006 to 60 per cent in 2009. This geographic expansion also confirms the improved landward accessibility of Incheon with regard to export flows towards Chinese forelands, with the aforementioned traffic shift towards Yellow Sea ports for short-sea shipping. The spatial shrinkage of total cargo hinterlands is, by contrast, better explained by local and national factors of congestion and reduced domestic demand, notably after the 2008 global financial crisis.

Figure 5: Incheon's hinterland flows, 2006-2009

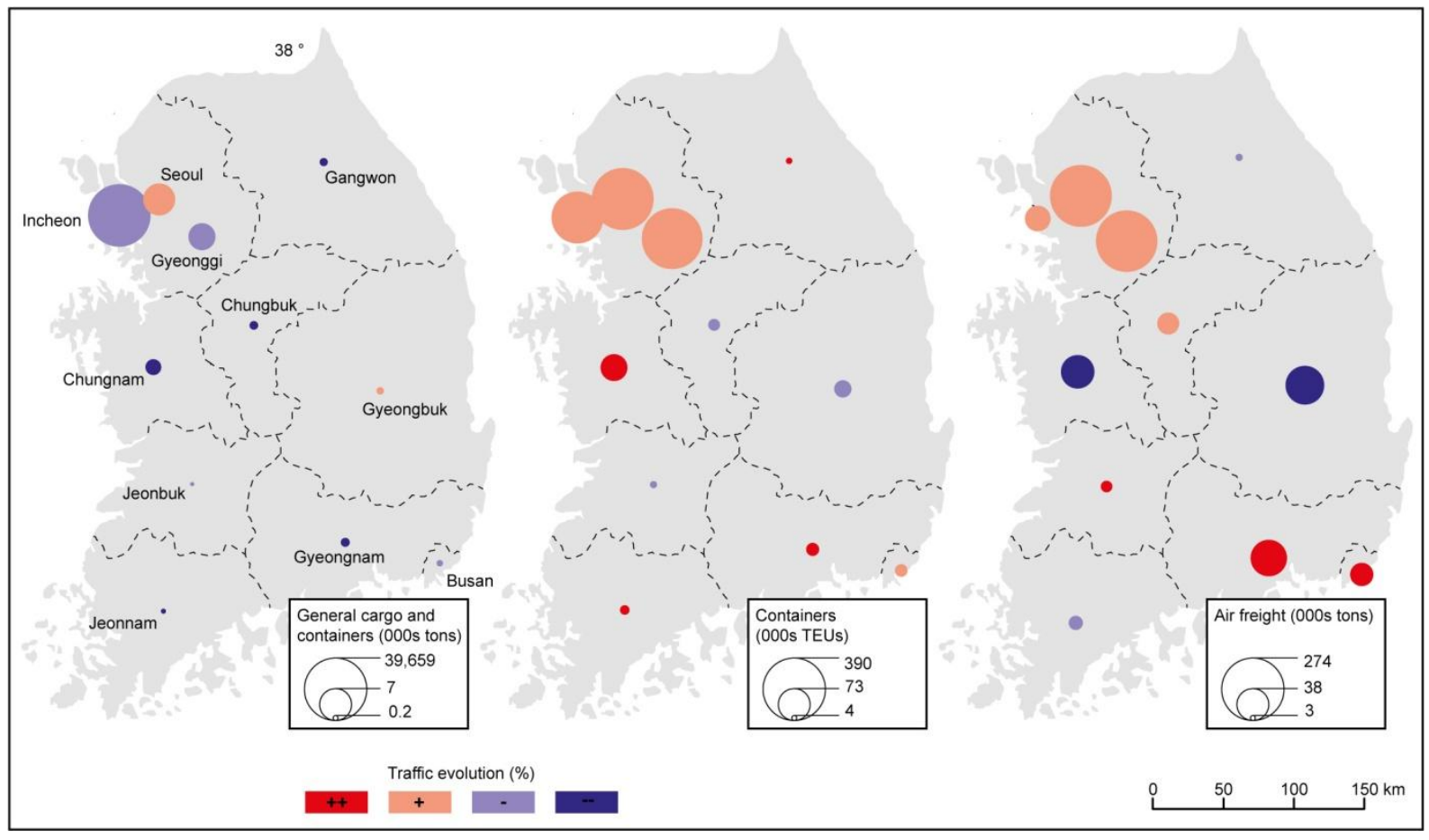

Source: own elaboration based on Korea Transport Database

In a survey about the success factors in the possible improvement of the IFEZ, Bang and Park (2005) highlighted the perceived importance of not only providing sufficient port and airport facilities (15 per cent of responses), but also the need to foster airport and seaport hinterlands (17 per cent). The role of Incheon as an economic centre in Korea and within the Gyeongin 
corridor is by contrast much lower with regard to air freight flows to and from the hinterland. A spatial division of hinterland traffic is currently taking place within the Capital Region, with Incheon handling flows for the northern part, reinforced by the Gyeongin waterway, and Pyongtaek ensuring traffic flows for the southern part.

\section{CONCLUSION: WINGS OF DESTINY?}

The examination of past and current developments in Incheon through the lense of urban and transport issues provide a contrasting picture of the situation. While Incheon may not, like in the legend of Icarus, be about to "fall" from its attempt to touch the shining model of the global city, there are certainly more efforts needed to better "ground" the future of this rapidly growing city. Also there is a need to better understand how different (except, perhaps, by the size) is Incheon's transformation from other waterfront redevelopment experiences and city models all over the world.

In terms of transport functions and options, the Pentaport concept has stimulated the development of diversity and integration, although the direct link between concept and practice remains questionable. Port and airport functions have increased in both absolute and relative terms on domestic and Northeast Asian levels since the early 2000s, with the modernisation and expansion of infrastructure. The rapid development of air-sea freight services with China as well as the planned completion of river canal shipping for ocean-river barges between China and Seoul through Incheon complement such dynamics. The growing density and connectedness of both the public transport system and the road system are very positive elements to reduce traffic congestion within Incheon as well as the mixing of commuting and trucking, which is typical of congested cities in developing countries. Such a 
picture is thus far from the one of Incheon as a specialized port gateway relying entirely on trucking. Nevertheless, more efforts are needed in terms of intermodalism to and from the port, despite the short distance between Seoul and Incheon hampering the establishment of rail services to further reduce truck flows along the main arteries. The shift of important logistics activities towards Pyongtaek is not the sign of improvement within Incheon itself.

Yet, intense competition among South Korean cities and the pursuit of economic growth through the IFEZ strategy do not seem to delete entirely the main tensions associated with freight flows in a large port city that Incheon continues to be. The coexistence of old and new functions within a relatively narrow space still faces problems of urban sprawl, environmental degradation, and social exclusion. Indeed, transport-related issues were somewhat left behind other matters by the Ministry of Finance and Economy and by the City itself (leader in the IFEZ project), in their pursuits of "urban entrepreneurialism" strategies. The spatial shrinkage of Incheon port's hinterland around the capital region during recent years has a global cause (overall fall in demand) but also reflects the expansion of nearby competitors domestically such as Pyongtaek in Gyeonggi province. Just like for many other large port cities of the world, the redevelopment of existing sites within the urban area is more costly than greenfield development at the urban fringe. Diversifying the maritime accessibility of the capital region is certainly desirable to relieve congestion from the main axis and reduce logistics costs; however, there is a risk to further spread transport-related negative impacts across the entire region.

The question whether Incheon becomes something else than a growing suburb or an edge city of an expanding Seoul remains difficult to answer since many developments are not yet completed. In many ways, Incheon's developments are simply "shifts" or "transfers" from 
Seoul, such as the international airport in Yeongjong island and the new university campus in Songdo district, among other examples. This is mostly explained by the lack of available space within Seoul and the peak rent values in a context of intense real estate speculation across the whole country. Instead of the emergence of a "new global city" in Incheon, we would rather talk about the expansion of the capital region (centred upon Seoul) through both spatial diffusion (within the capital region) and spatial concentration (within the country). In such transfers the local authority seems to follow the guidelines of the central government rather than to develop its own solutions and projects, which remain largely influenced by external views on what Incheon should become.

When there is no further space in Seoul and while Busan is too far, Incheon appears as the logical choice for such policies, notably profiting from existing infrastructure, highly proactive and entrepreneurialism-based urban management, and all the advantages of developing new real estate and functions in sea-reclaimed "virgin" land. What remains problematic is the growing social and economic divide within the city, between the IFEZ as a new enclave (in terms of architecture and amenities, English speaking, level of schools and services within the new city) and the rest of the city, which does not seem to be included in the project mostly focussed on the domestic and foreign upper class. If the IFEZ succeeds in attracting and fixing new residents, it will, at least, help decongest Seoul and the capital region as a whole, but the way towards local integration (both physical, social, and economic) between old and new remains to be seen.

\section{ACKNOWLEDGEMENTS}

Luis de Carvalho thanks the financial support of the Portuguese Foundation for Science and Technology. We thank Chung Tae Won and Lee Kwon-Hyung (IDI) for their valuable 
support in collecting some of the data that we used in this chapter. The content and opinion expressed in the chapter are yet of the authors solely.

\section{BIBLIOGRAPHY}

Bang, H.S. and Park, K.S. (2005) Factors to be considered for improving Free Economic Zone in Korea, Paper presented at the International Conference on WTO, China, and the Asian Economies, III: Economic Integration and Economic Development, Xi'an Jiatong University, Xi'an, China, June 25-26. Online. Available HTTP: <http://faculty.washington.edu/karyiu/confer/xian05/papers/bang.pdf> (accessed June 2011).

Carvalho, L., van Tuijl, E., and J. van Haaren (2011) Developing Locations in the Knowledge Economy: Incheon, Rotterdam: Euricur.

Carvalho, L. (2011) 'Urban competitiveness, u-city strategies and the development of technological niches in Songdo, South Korea', in M. Bulu (ed.) City Competitiveness and Information Science: Technologies for Synchronizing Urban Subsystems, Pennsylvania: IGI Global.

Chang, Y.T. (2003) 'Korea's strategic plan to be Northeast Asia's logistics hub: towards the Pentaport approach', Korea Observer, 34: 437-60.

Choi, Y.J. and Ryu, J.H. (2000) 'Inchon: gateway to Seoul', 29th International Geographical Congress, Seoul: Korea National University.

Choo, M.G. (1998) 'The role of Seoul port in strengthening economic cooperation between China and Korea', The Proceedings of Yellow Sea Transportation System, Wuxi (China), 4-7 November, pp. 32-5.

Chung, D.Y. and Kato, A. (1998) 'Process of urbanization in the reclaimed land in Inchon city, Korea', Technology Reports of the Osaka University, 48: 91-106.

Cullinane, K. and Song, D.W. (1998) 'Container terminals in South Korea: problems and panaceas', Maritime Policy and Management, 25: 63-80.

Ducruet, C. (2010) 'Free economic zones in North Korea and South Korea', in F. Bost (ed.) Atlas Mondial des Zones Franches, Paris: La Documentation Française, pp. 242-53 (in French).

Ducruet, C., Lee, S.W. and Roussin, S. (2009a) 'Local strength, global weakness: a maritime network perspective on South Korea as Northeast Asia's logistics hub', Korea Maritime Institute (KMI) International Journal of Maritime Affairs and Fisheries, 1: 32-50.

Ducruet, C., Roussin, S. and Jo, J.C. (2009b) 'Going West? Spatial polarization of the North Korean port system', Journal of Transport Geography, 17: 357-68.

Frémont, A. and Ducruet, C. (2005) 'The emergence of a mega-port: from the local to the global, the case of Busan', Tijdschrift voor Economische en Sociale Geografie, 96: 421-432.

Fujita, M. and Mori, T. (1996) 'The role of ports in the making of major cities: self-agglomeration and hub-effect', Journal of Development Economics, 49: 93-120. 
Gelézeau, V. (ed.) (2005) La Corée en miettes, Paris: L'Harmattan.

Hankyoreh (2009) 'Land Ministry moves forward with Gyeongin Canal construction: environmental groups express concerns about inconsistent reports on the economic efficiency of the plan', January 6. Online. Available HTTP: <http://english.hani.co.kr/arti/english_edition/e_national/331534.html> (accessed August 2011).

Hong, S.W. (1996) 'Seoul: a global city in a nation of rapid growth', in F.C. Lo and Y.M. Yeung (eds.) Emerging World Cities in Pacific Asia, Tokyo-New-York-Paris: United Nations University Press, pp. 14478.

IDI (2010) Urban Plans of Incheon Metropolitan City, Incheon: Incheon Development Institute.

IFEZ (2009) Welcome. Incheon Free Economic Zone. Institutional Presentation. Incheon: IFEZ Public Relations Office.

IFEZ (2010) Business Hub of Asia - Incheon Free Economic Zone. Incheon: IFEZ Public Relations Office.

Incheon Metropolitan City (2004) Atlas of Incheon 1882-2001.

IT Times (2009) 'Incheon strives to be reborn as world-class global city', June 4. Online. Available HTTP: <http://www.koreaittimes.com/story/3651/incheon-strives-be-reborn-world-class-global-city> (Accessed June 2011).

Joongang Daily (2011) 'That's one tall order'. June 23. Online. Available HTTP: <http://joongangdaily.joins.com/article/view.asp?aid=2937928> (accessed June 2011)

Joongang Daily (2011) 'How Incheon plans to soar', April 22. Online. Available HTTP: $<$ http://joongangdaily.joins.com/article/view.asp?aid=2935193> (accessed June 2011)

Jun, I.S. and Park, C. (1991) 'Port-city relations in Korea', in 4th International Academy of Maritime and Ports Conference, Vol. 4, Seoul: International Academy Announcement, Conference Theses Collection, pp. 103-23.

Jun, I.S. (2003) 'An agenda for the Incheon Free Economic Zone - Developing Quad Ports and Quad Parks'. Journal of International Logistics and Trade, 1: 85-105.

Jun, M.J. (2011) 'The effects of Seoul's greenbelt on the spatial distribution of population and employment, and on the real estate market', The Annals of Regional Science, DOI: 10.1007/s00168011-0461-5

Kim, C. (2010) 'Place promotion and symbolic characterization of New Songdo City, South Korea', Cities, 27: 13-9.

Kim, G.S. (2005) 'Revitalization of the logistic function of the Free Economic Zone', KRIHS Gazette, Korean Research Institute on Human Settlements, 22: 1-3.

Kim, H. (2007) 'Regional innovation policy of South Korea, compared with, and learning from, the European Union', Paper presented at the European Union Center of Excellence and Center for East Asian Studies, University of Wisconsin-Madison. 
Kim, H.S. (2000) "Long-term policy for the development of Korean ports in the 21 st century", Korea Maritime Institute Reports, pp. 275-302, online, available at: http://118.129.184.33/pub/docu/kr/AM/06/AM061999B01/AM06-1999-B01-012.HTM

Kim, K.S. and Hwang, K. (2003) 'Critical issues in transformation of transportation policy in Korean metropolitan areas', Journal of the Eastern Asia Society for Transportation Studies, 5: 3142-57.

Kim, S. (2007) The spatial concepts of the Incheon port vicinities redevelopment project, Master Thesis in Community and Regional Planning, University of Oregon, Department of Planning, Public Policy and Management, May.

Kim, W.S. and Lee, Y.I. (2007) 'Challenges of Korea's foreign direct investment-led globalization: multinational corporations' perceptions', Asia Pacific Business Review, 13: 163-81.

Lee, D.B., Kim, Y.H., Hong, S.P., Hori, T. and Ito, T. (1998) 'A study on the development process of Inchon as industrial city and its on-going trend of transformation', Paper presented at the 1st International Symposium on City Planning and Environmental Management in Asian Countries, Ujung Pandang: Asian Urban Research Group.

Lee, J. and Oh, J. (2008) New Songdo City and the value of flexibility: a case study of implementation and analysis of a mega-scale project, Master Thesis in Real Estate Development, Massachusetts Institute of Technology.

Lee, J.Y. and Rodrigue, J.P. (2006) 'Trade reorientation and its effects on regional port systems: the Korea-China link along the Yellow Sea rim', Growth and Change, 37: 597-619.

Lee, S.W. and Kim, G.S. (2009) 'Port challenge in Northeast Asia: Korea's two-hub port strategy', in T.E. Notteboom, C. Ducruet and P.W. De Langen (eds.) Ports in Proximity: Competition and Cooperation among Adjacent Seaports, Aldershot: Ashgate, pp. 247-260.

Lee, Y.S. (1999) 'The Masan Free Export Zone: conflict and attrition', in A.R. Markusen, Y.S. Lee and S. Di Giovanna (eds.) Second Tier Cities: Growth Beyond the Metropolis, Minneapolis: University of Minnesota Press, pp. 183-98.

Lee, Y.S. (2004) 'Debt restructuring and the politics of exclusion: a case study of the Daewoo Motor Bupyeong plants in Incheon, South Korea', Urban Studies, 41: 2395-2414.

Miller, M.L. and Kim, S.G. (2004) 'Leisure port development in the Incheon area: concepts and benchmarks', Journal of International Logistics and Trade, 2: 5-45.

Park, Y. (2003) 'An analysis for the competitive strength of Asian major airports', Journal of Air Transport Management, 9: 353-60.

Park, S.O. and Markusen, A.R. (1999) 'Kumi and Ansan: dissimilar Korean satellite platforms', in A.R. Markusen, Y.S. Lee and S. Di Giovanna (eds.) Second Tier Cities: Growth Beyond the Metropolis, Minneapolis, University of Minnesota Press, pp. 147-81.

Rimmer, P.J. (2004a) 'Marketing Incheon: gateway for Seoul, Northeast Asia and the world', Journal of International Logistics and Trade, 2: 99-121.

Rimmer, P.J. (2004b) 'Global flows, local hubs, platforms and corridors: regional and economic integration in Northeast Asia', Journal of International Logistics and Trade, 1: 1-24. 
Rimmer, P.J. and Chang, Y.T. (2004) 'Incheon Pentaport - five ports in one: seeking its conceptual underpinning', Paper presented at the Three Consecutive Events Celebrating 50th Anniversary of INHA University, 27-29 April 2004.

Roth, J. (2011) South Korea and Northeast Asian Logistics, Master Thesis in Business Administration, Reims Management School, France (in French).

Sang, H.L., Jung, H.H., Yoon, T.L. and Tan, Y. (2008) 'Towards ubiquitous city: concept, planning, and experiences in the Republic of Korea', in T. Yigitcanlar, K. Velibeyoglu and S. Baum (eds.) KnowledgeBased Urban Development: Planning and Applications in the Information Era, IGI Global, Information Science Reference, Hershey, Pa, pp. 148-69.

Shin, D.C. (2005) 'Recent experience of and prospects for high-speed rail in Korea: implications of a transport system and regional development from a global perspective', Working Paper 2005-02, Institute of Urban and Regional Development, University of California, Berkeley.

Ship-Technology (2011) Gyeongin Canal to Open By October, January 12. Online. Available HTTP: $<$ <ttp://www.ship-technology.com/news/news106845.html> (accessed June 2011).

Smith, D.A. (1981) 'Semiperipheral urbanization? South Korea in the 1980s', in R. Kasaba (ed.) Cities in the World System, Contribution in Economics and Economic History, $n^{\circ} 126$ New York/Westport/London: Greenwood Press, pp. 157-73.

Song, Y., Lee, K., Anderson, W.P. and Lakshmanan, T.R. (2011) 'Industrial agglomeration and transport accessibility in metropolitan Seoul', Journal of Geographical Systems, DOI: 10.1007/s10109-011-0150-z

Van Winden, W., van den Berg, L., Carvalho, L. and van Tuijl, E. (2011) Manufacturing in the New Urban Economy, London: Routledge.

Wallace, R. (2004) 'Avec la nouvelle ville de Songdo, la Corée du Sud lutte pour le prestige régional', EE Times, May 25. Online (accessed 2007). 